\title{
HUBUNGAN ASUPAN KAFEIN DENGAN KADAR ASAM URAT DI PUSKESMAS BANJARNEGARA
}

\author{
Eka Hermawati, Enny Probosari ${ }^{*}$ \\ Program Studi Ilmu Gizi Fakultas Kedokteran Universitas Diponegoro \\ Jl.Dr.Sutomo No.18, Semarang, Telp (024) 8453708, Email : gizifk@undip.ac.id
}

\begin{abstract}
Background: Hyperuricemia caused by increased uric acids levels in the body. One factor increased of uric acids levels was factor intake, namely was excessive of purines intake. However, caffeine consumption can be lower uric acid levels because caffeine has a chemical structure that resembles a uric acid lowering drugs.

Methods: This research was observational study with the design of case-control. Subjects were people aged 45-88 years for case and control group. The levels of uric acids in the blood was measured with colotimetric test, and nutrient intake history data such as, carbohydrate, fat, protein, fluid, purine and caffeine obtained through interviews using a semi-quantitatives Food Frequency Questionare. Bivariate analysis using Chi Square test

Results:Mean of uric acids levels was 6,3 $\mathrm{mg} / \mathrm{dl} \pm 0,67 \mathrm{SD}$ for the case group and 4,6 $\mathrm{mg} / \mathrm{dl} \pm 0,73 \mathrm{SD}$ for control group. The most significant risk factors on increased uric acids levels was high intake of carbohydrate $(p=0,028 ; O R=4,36)$, while high intake of caffeine was not risk factor between low uric acids levels $(p=0,546 ; O R=0,69)$

Conclusion: High intake of caffeine had not risk factor with low uric acids levels in Puskesmas Banjarnegara Keyword: Caffeine, uric acids levels
\end{abstract}

\begin{abstract}
ABSTRAK
Latar Belakang: Hiperurisemia disebabkan karena meningkatnya kadar asam urat di dalam tubuh. Salah satu faktor peningkatan kadar asam urat adalah faktor asupan, yaitu asupan purin yang berlebihan. Namun, konsumsi kafein dapat menurunkan kadar asam urat karena kafein mempunyai stuktur kimia yang menyerupai obat penurun asam urat.

Metode: Penelitian ini termasuk penelitian observasi dengan desain kasus-kontrol. Jumlah subyek penelitian adalah 23 orang dengan usia 45-88 tahun untuk masing-masing kelompok kasus dan kelompok kontrol. Kadar asam urat dalam darah diukur dengan uji kolorimetri, dan data riwayat asupan makanan seperti asupan karbohidrat, lemak, protein, cairan, purin dan kafein diperoleh dengan wawancara menggunakan Food Frequency Questionare semi kuantitatif. Analisis bivariat menggunakan uji Chi Square

Hasil: Rata-rata kadar asam urat pada kelompok kasus adalah 6,3 mg/dl $\pm 0,67 \mathrm{SD}$, sedangkan untuk kelompok kontrol adalah 4,6 mg/dl $\pm 0,73 \mathrm{SD}$. Faktor risiko yang berpengaruh terhadap peningkatan kadar asam urat adalah asupan karbohidrat yang tinggi $(p=0,028 ; O R=4,36)$, sedangkan asupan kafein tinggi tidak memiliki factor risiko yang bermakna dengan penurunan kadar asam urat $(p=0,546 ; O R=0,69)$
\end{abstract}

Kesimpulan: Asupan tinggi kafein bukan factor risiko dengan penurunan kadar asam urat di Puskesmas Banjarnegara

Kata Kunci: Kafein, kadar asam urat

\section{PENDAHULUAN}

Penyakit gout merupakan salah satu penyakit degeneratif yang terjadi karena adanya peningkatan kadar asam urat di dalam darah. Batas kejenuhan asam urat dalam serum pada laki-laki adalah $7,0 \mathrm{mg} / \mathrm{dl}$ dan pada perempuan $5,7 \mathrm{mg} / \mathrm{dl}$. Hiperurisemia terjadi apabila seseorang memiliki kadar asam urat melebihi batas kejenuhan kadar asam urat tersebut. ${ }^{1}$

Asam urat merupakan hasil akhir dari metabolisme purin (adenine dan guanine) yang dihasilkan dalam jaringan yang mengandung enzim xanthine oxidase terutama di hati dan usus halus. Sumber asam urat pada manusia terdapat pada proses endogen maupun eksogen. Proses endogen terjadi alami di dalam tubuh manusia dari sintesis de novo dan pemecahan asam nukleat, sedangkan proses eksogen berasal dari asupan makanan yang mengandung purin. ${ }^{2}$ Meningkatnya asam urat yang berlebihan juga disebabkan karena kelebihan pembentukan asam urat di dalam tubuh atau terhambatnya pembuangan asam urat oleh tubuh. ${ }^{3}$

Data National Health and Nutrition Examination Survey (NHANES III), menyebutkan prevalensi hiperurisemia pada orang dewasa di Amerika Serikat mengalami peningkatan selama lebih dari 10 tahun terakhir yaitu $2,7 \%$ pada tahun 1994 dan menjadi $3,9 \%$ pada tahun $2008^{4}$. Berdasarkan data Riskesdas tahun 2013, prevalensi penyakit sendi pada usia 55 - 64 tahun $45,0 \%$, usia $65-74$ tahun 51,9 , usia $\geq 75$ tahun $54,8 \%$. Penyakit sendi yang sering dialami oleh golongan lanjut usia 
yaitu penyakit artritis gout, osteoarthritis dan artritis reuomatoid. ${ }^{5}$ Penelitian di Puskesmas Mandiraja Kabupaten Banjarnegara sendiri menunjukkan bahwa kasus hiperurisemia yang cukup tinggi, yaitu sebanyak 55 pasien dari 199 orang $(27,6 \%)$ pada tahun 2011 dan meningkat pada tahun 2012 yaitu 42 pasien dari 71 orang (59\%). Sedangkan berdasarkan data dari klinik gizi di Puskesmas Banjarnegara, dari bulan Januari hingga April 2015 terdapat 36 pasien yang menderita hiperurisemia dari 82 orang yang memeriksakan kadar asam urat.

Masyarakat dunia bahkan Indonesia mempunyai kebiasaan mengonsumsi minuman maupun bahan makanan seperti kopi, teh, coklat, dan minuman bersoda. Minuman atau bahan makanan tersebut menjadi trend di zaman modern seperti saat ini. Makanan/minuman tersebut telah diketahui memiliki kandungan kafein. Sifat kafein yang mempunyai struktur kimia methylxantin telah diketahui dapat menurunkan kadar asam urat di dalam tubuh. Selain itu, struktur kimia pada kafein memiliki kemiripan dengan obat penurun asam urat yaitu allopurinol. ${ }^{3}$ Sebuah penelitian di Jepang pada subyek usia dewasa diungkapkan bahwa konsumsi minuman yang mengandung kafein seperti kopi dan teh pada jangka panjang dapat menurunkan kadar asam urat. ${ }^{7}$ Sedangkan pada penelitian Choi pada tahun 2007 juga mengungkapkan bahwa asupan kafein dari seluruh sumber makanan tidak berpengaruh pada risiko penyakit gout. ${ }^{1}$ Berdasarkan ulasan tersebut, dilakukan penelitian tentang hubungan asupan kafein dengan kadar asam urat di Puskesmas Banjarnegara.

\section{METODE PENELITIAN}

Penelitian ini dilaksanakan di Puskesmas Banjarnegara Kabupaten Banjarnegara pada bulan Juni 2014. Penelitian ini termasuk dalam ruang lingkup keilmuan gizi masyarakat dengan desain penelitian kasus-kontrol yang menggunakan pendekatan retrospektif. Subyek dalam penelitian ini adalah pria dan wanita berusia 45-88 tahun. Kriteria inklusi subyek meliputi bersedia menjadi sampel penelitian dengan mengisi informed consent, dapat berkomunikasi dengan baik, memiliki kadar asam urat tinggi pada laki-laki>7 $\mathrm{mg} / \mathrm{dl}$, sedangkan perempuan $>5,7 \mathrm{mg} / \mathrm{dl}$ untuk kelompok kasus, dan memiliki kadar asam urat normal untuk kelompok kontrol. Berdasarkan perhitungan besar sampel, diperoleh jumlah sampel minimal sebanyak 46 sampel dengan pembagian sampel untuk kelompok kasus maupun kelompok kontrol sebanyak 23 sampel. Cara pengambilan sampel pada penelitian ini dilakukan dengan cara non-probality sampling yang cara pengambilan sampel tidak berdasarkan peluang. Jenis pengambilan sampel adalah consecutive sampling yaitu semua subjek yang datang dan memenuhi kriteria inklusi dimasukkan dalam penelitian..

Variabel bebas dalam penelitian ini adalah asupan kafein, dan variabel terikat dalam penelitian ini adalah kadar asam urat darah. Variabel perancu adalah asupan karbohidrat, lemak, protein, cairan, purin dan status gizi. Data beberapa asupan tersebut diperoleh melalui FFQ (Food Frequency Questionare) semi kuantitatif dengan metode wawancara. Sedangkan untuk data status gizi diperoleh menggunakan data antropometri. Data kadar asam urat diperoleh melalui pembuluh vena dalam satuan $\mathrm{mg} / \mathrm{dl}$ yang dilakukan dengan uji kolorimetri oleh pihak laboratorium, dimana kadar asam urat dikatakan tinggi pada laki-laki apabila melebihi $7,0 \mathrm{mg} / \mathrm{dl}$ dan pada perempuan apabila melebihi $5,7 \mathrm{mg} / \mathrm{dl} .{ }^{1}$

Asupan kafein merupakan jumlah rerata asupan kafein subyek yang berasal dari makanan atau minuman yang dianalisis menggunakan daftar kandungan kafein pada bahan makanan atau minuman. Rata-rata kebutuhan asupan kafein pada setiap individu yaitu $1,73 \mathrm{mg} / \mathrm{kg}$ berat badan, dikatakan tinggi apabila asupan kafein melebihi kebutuhan dan dikatakan rendah apabila asupan kafein kurang dari kebutuhan. ${ }^{8}$ Asupan karbohidrat, lemak dan protein adalah jumlah rerata asupan karbohidrat, lemak dan protein subyek yang berasal dari makanan utama atau makanan selingan yang mengandung karbohidrat, lemak dan protein dimana asupan dikatakan tinggi jika asupan melebihi $80 \%$ dari kebutuhan dan dikatakan rendah apabila asupan $\leq 80 \%$ dari kebutuhan. Asupan cairan adalah jumlah rerata asupan cairan subyek yang berasal dari minuman yang dikonsumsi perhari dengan rata-rata kebutuhan asupan cairan setiap individu yaitu $30 \mathrm{ml} / \mathrm{kg}$ berat badan, dimana dikatakan kurang apabila asupan $\leq 80 \%$ dan cukup apabila asupan melebihi $80 \%$ dari kebutuhan. Asupan purin adalah jumlah rerata asupan purin subyek yang berasal dari makanan utama atau makanan selingan yang mengandung purin dimana asupan purin kurang $\leq 500 \mathrm{mg} /$ hari dan asupan purin tinggi $>1000 \mathrm{mg} /$ hari. $^{9} \quad$ Status gizi subyek diklarifikasikan berdasarkan IMT untuk orang AsiaPasifik dimana IMT $<18,5 \mathrm{~kg} / \mathrm{m}^{2}$ dikatakan kurus, $18,5-18,5-22,9 \mathrm{~kg} / \mathrm{m}^{2}$ tergolong normal, 23$29,9 \mathrm{~kg} / \mathrm{m}^{2}$ termasuk overweight dan $>30 \mathrm{~kg} / \mathrm{m}^{2}$ tergolong obesitas.

Analisis data meliputi analisis univariat dan bivariat. Analisis univariat dilakukan untuk mendeskripsikan karakteristik subyek. Analisis 
bivariat menggunakan uji Chi Square. Analisis hasil penelitian pada desain kasus-kontrol juga dilakukan dengan cara menentukan OR (Odds Ratio).

\section{HASIL PENELITIAN}

\section{Karakteristik subyek penelitian}

Karakteristik subyek pada penelitian ini terdiri dari usia, jenis kelamin dan status gizi. Subyek berjumlah 46 orang dengan jumlah 23 orang untuk kelompok kasus dan 23 orang untuk kelompok kontrol. Rerata kadar asam urat subyek pada kelompok kasus adalah 6,3 mg/dl $\pm 0,67$ dan 4,6 $\mathrm{mg} / \mathrm{dl} \pm 0,73$ pada kelompok kontrol. Hasil penelitian menunjukkan bahwa kategori usia $\geq 60$ tahun lebih banyak pada kelompok kasus maupun kelompok kontrol $(65 \%)$ dibandingkan dengan usia $\leq 60$ tahun pada kelompok kasus maupun kelompok kontrol (35\%). Distribusi frekuensi subyek menurut kategori variabel penelitian dapat dilihat pada Tabel 1.

Tabel 1. Distribusi frekuensi Usia, Jenis Kelamin dan Status Gizi.

\begin{tabular}{|c|c|c|c|c|}
\hline \multirow[t]{2}{*}{ Variabel } & \multicolumn{2}{|c|}{ Kasus } & \multicolumn{2}{|c|}{ Kontrol } \\
\hline & $\mathrm{n}$ & $\%$ & $\mathrm{n}$ & $\%$ \\
\hline \multicolumn{5}{|l|}{ Usia } \\
\hline$-\quad \leq 60$ tahun & 8 & 35 & 8 & 35 \\
\hline$-\quad \geq 60$ tahun & 15 & 65 & 15 & 65 \\
\hline \multicolumn{5}{|l|}{ Jenis Kelamin } \\
\hline - Perempuan & 20 & 87 & 20 & 87 \\
\hline - Laki-laki & 3 & 13 & 3 & 13 \\
\hline \multicolumn{5}{|l|}{ Status Gizi } \\
\hline - $\quad$ Normal $\left(18,5-22,9 \mathrm{~kg} / \mathrm{m}^{2}\right)$ & 7 & 30 & 7 & 30 \\
\hline - $\quad$ Overweight $\left(23-29,9 \mathrm{~kg} / \mathrm{m}^{2}\right)$ & 14 & 65 & 14 & 65 \\
\hline - $\quad$ Obesitas $\left(>30 \mathrm{~kg} / \mathrm{m}^{2}\right)$ & 2 & 5 & 2 & 5 \\
\hline
\end{tabular}

Berdasarkan Tabel 1, jenis kelamin subyek pada kelompok kasus maupun kontrol lebih banyak pada perempuan $(87 \%)$ dibandingkan laki-laki (13\%). Status gizi subyek sebagian besar adalah overweight. Sebagian besar subyek berstatus gizi overweight, status gizi overweight pada kelompok kasus sebanyak $61 \%$, sedangkan pada kelompok control sebanyak $52 \%$.

Tabel 2. Distribusi frekuensi asupan Karbohidrat, Lemak, Purin, Cairan, Kafein dan Status Gizi

\begin{tabular}{|c|c|c|c|c|}
\hline \multirow[t]{2}{*}{ Variabel } & \multicolumn{2}{|c|}{ Kasus } & \multicolumn{2}{|c|}{ Kontrol } \\
\hline & $\mathrm{n}$ & $\%$ & $\mathrm{~N}$ & $\%$ \\
\hline \multicolumn{5}{|l|}{ Asupan Karbohidrat (g/hr) } \\
\hline - $\quad$ Normal (80-100\% kebutuhan) & 4 & 17 & 11 & 48 \\
\hline - $\quad$ Tinggi (>100\% kebutuhan) & 19 & 83 & 12 & 52 \\
\hline \multicolumn{5}{|l|}{ Asupan Lemak (g/hr) } \\
\hline - Normal (80-100\% kebutuhan) & 1 & 4 & 2 & 9 \\
\hline - Tinggi (>100\% kebutuhan) & 22 & 96 & 21 & 91 \\
\hline \multicolumn{5}{|l|}{ Asupan Protein $(\mathrm{g} / \mathrm{hr})$} \\
\hline - Normal (80-100\% kebutuhan) & 2 & 9 & 3 & 13 \\
\hline - Tinggi (>100\% kebutuhan) & 21 & 91 & 20 & 87 \\
\hline \multicolumn{5}{|l|}{ Asupan Purin $(\mathrm{mg} / \mathrm{hr})$} \\
\hline - Rendah $(<500$ mg/hari $)$ & 14 & 61 & 14 & 61 \\
\hline - $\quad$ Normal (500-1000 mg/hari) & 9 & 39 & 9 & 39 \\
\hline \multicolumn{5}{|l|}{ Asupan Cairan (ml/hr) } \\
\hline - $\quad$ Rendah $(<1500 \mathrm{ml} / \mathrm{hari})$ & 15 & 65 & 16 & 70 \\
\hline - $\quad$ Normal (>1500 ml/hari) & 8 & 35 & 7 & 30 \\
\hline \multicolumn{5}{|l|}{ Asupan Kafein $(\mathrm{mg} / \mathrm{hr})$} \\
\hline - Tinggi & 10 & 43 & 8 & 35 \\
\hline - Rendah & 13 & 57 & 15 & 65 \\
\hline \multicolumn{5}{|l|}{ Status Gizi } \\
\hline - Tidak berlebih & 7 & 30 & 7 & 30 \\
\hline - Berlebih & 16 & 70 & 16 & 70 \\
\hline
\end{tabular}

Berdasarkan Tabel 2 menunjukkan bahwa asupan karbohidrat pada kelompok kasus tergolong tinggi yaitu $83 \%$ dibandingkan dengan kelompok kontrol (52\%). Asupan kafein tinggi pada kelompok kasus (43\%) lebih tinggi dibandingkan dengan kelompok kontrol (35\%). Sedangkan untuk status 
gizi, 70\% memiliki status gizi berlebih baik pada

kelompok kasus maupun kelompok kontrol.

Tabel 3. Hubungan asupan karbohidrat, lemak, protein, purin, cairan, kafein dan status gizi dengan kadar asam urat

\begin{tabular}{|c|c|c|c|c|c|c|c|}
\hline \multirow{2}{*}{\multicolumn{2}{|c|}{ Variabel }} & \multicolumn{2}{|c|}{ Kasus } & \multicolumn{2}{|c|}{ Kontrol } & \multirow[t]{2}{*}{ OR $(95 \% \mathrm{CI})$} & \multirow[t]{2}{*}{$\mathrm{p}$} \\
\hline & & $\mathrm{n}$ & $\%$ & $\mathrm{~N}$ & $\%$ & & \\
\hline \multicolumn{8}{|c|}{ AsupanKarbohidrat (g/hr) } \\
\hline- & Normal & 4 & 17 & 11 & 48 & \multirow[t]{2}{*}{$4,36(1,1-16,9)$} & \multirow[t]{2}{*}{$0,057^{\mathrm{b}, \mathrm{c}}$} \\
\hline- & Tinggi & 19 & 83 & 12 & 52 & & \\
\hline \multicolumn{8}{|c|}{ Asupan Lemak (g/hr) } \\
\hline- & Normal & 1 & 4 & 2 & 9 & \multirow[t]{2}{*}{$2,095(0,177-24,865)$} & \multirow[t]{2}{*}{$0,550^{\mathrm{a}}$} \\
\hline & Tinggi & 22 & 96 & 21 & 91 & & \\
\hline \multicolumn{8}{|c|}{ Asupan Protein $(\mathrm{g} / \mathrm{hr})$} \\
\hline- & Normal & 2 & 9 & 3 & 13 & \multirow[t]{2}{*}{$1,575(0,238-10,437)$} & \multirow[t]{2}{*}{$0,636^{\mathrm{a}}$} \\
\hline & Tinggi & 21 & 91 & 20 & 87 & & \\
\hline \multicolumn{8}{|c|}{ Asupan Purin (mg/hr) } \\
\hline- & Rendah & 14 & 61 & 14 & 61 & \multirow[t]{2}{*}{$1,000(0,306-3,268)$} & \multirow[t]{2}{*}{$1,000^{\mathrm{a}}$} \\
\hline- & Normal & 9 & 39 & 9 & 39 & & \\
\hline \multicolumn{8}{|c|}{ Asupan Cairan (ml/hr) } \\
\hline- & Rendah & 15 & 65 & 16 & 70 & \multirow[t]{2}{*}{$0,820(0,239-2,820)$} & \multirow[t]{2}{*}{$0,753^{\mathrm{a}}$} \\
\hline- & Normal & 8 & 35 & 7 & 30 & & \\
\hline \multicolumn{8}{|c|}{ Asupan Kafein (mg/hr) } \\
\hline- & Tinggi & 10 & 43 & 8 & 35 & \multirow[t]{2}{*}{$0,69(0,21-2,27)$} & \multirow[t]{2}{*}{$0,546^{\mathrm{a}}$} \\
\hline- & Rendah & 13 & 57 & 15 & 65 & & \\
\hline \multicolumn{8}{|l|}{ Usia } \\
\hline- & $<60$ tahun & 8 & 35 & 8 & 35 & \multirow[t]{2}{*}{$1,000(0,297-3,365)$} & \multirow[t]{2}{*}{$1,000^{\mathrm{a}}$} \\
\hline- & $\geq 60$ tahun & 15 & 65 & 15 & 65 & & \\
\hline \multicolumn{8}{|c|}{ Status Gizi } \\
\hline- & Tidak berlebih & 7 & 30 & 7 & 30 & \multirow[t]{2}{*}{$1,000(0,285-3,512)$} & \multirow[t]{2}{*}{$1,000^{\mathrm{a}}$} \\
\hline- & Berlebih & 16 & 70 & 16 & 70 & & \\
\hline
\end{tabular}

${ }^{\mathrm{a} U j i}$ Chi Square, ${ }^{\mathrm{b}} \mathrm{Uji}$ Fisher, ${ }^{\mathrm{c}}$ signifikan $\mathrm{p}<0,05$

Tabel 3 menunjukkan bahwa asupan karbohidrat tinggi merupakan faktor risiko kadar asam urat tinggi yang bermakna dengan $p$ value $<0,05$. Sedangkan asupan kafein rendah merupakan faktor risiko kadar asam urat tinggi yang secara statistik tidak bermakna ( $p$ value $>0,05$ ) dengan nilai OR 0,69.

\section{PEMBAHASAN}

Penelitian ini menunjukkan bahwa sebagian besar subyek adalah wanita dan berusia $\geq 60$ tahun. Usia dan jenis kelamin merupakan faktor risiko terjadinya peningkatan kadar asam urat. Peningkatan kadar asam urat pada wanita terjadi karena adanya proses menopause yang mengakibatkan menurunnya produksi hormon esterogen. Hormon esterogen berfungsi sebagai uricosuric agent. Mekanisme uricosuric agent dalam ekskresi asam urat adalah dengan menghambat URAT1 (urate transporter-1) dari lumen ke sel tubular proksimal pada saat pengaturan keseimbangan cairan elektrolit. Sedangkan hubungan usia subyek dengan peningkatan kadar asam urat dikarenakan terjadinya proses penuaan yang mengakibatkan menurunnya fungsi organorgan di dalam tubuh seperti penurunan fungsi ginjal terhadap kecepatan filtrasi, eskresi, dan reabsorbsi terhadap metabolisme asam urat. ${ }^{10,11}$ Usia dalam penelitian ini tidak memiliki faktor risiko terhadap kadar asam urat, kemungkinan disebabkan karena perbedaan gaya hidup, riwayat penyakit dan asupan zat gizi. ${ }^{10}$

Penelitian ini juga menunjukkan bahwa status gizi subyek sebagian besar adalah overweight (65\%) pada masing-masing kelompok kasus dan kelompok kontrol. Peningkatan IMT (Indeks Massa Tubuh) merupakan faktor risiko terjadinya gout. Pada orang yang mengalami status gizi berlebih, terjadi peningkatan koenzim A untuk asam lemak rantai panjang. Koenzim ini berkaitan erat dengan sindrom resistensi insulin. Adanya resistensi insulin akan menyebabkan tingginya koenzim A sehingga mengakibatkan terhambatnya kerja Adenosin Nukleotide Translocator (ANT) sehingga adenosine ekstrasel meningkat. Peningkatan adenosine ekstrasel ini menyebabkan peningkatan asam urat plasma melalui terbentuknya urat dari adenosine tersebut. Namun, pada penelitian ini, status gizi 
overweight tidak memiliki faktor risiko dengan kadar asam urat. Hal ini kemungkinan disebabkan karena adanya pengaruh hormon leptin yang meningkat seiring dengan meningkatnya kadar asam urat dalam darah ${ }^{12,13}$

Meningkatnya kadar asam urat dalam darah dipengaruhi oleh beberapa faktor seperti genetik, usia, jenis kelamin, obat, riwayat penyakit, asupan makanan, alkohol, asupan cairan dan obesitas. Namun pada umumnya, kelebihan kadar asam urat dipengaruhi oleh metabolisme asam urat yang terjadi di luar tubuh melalui asupan makanan yang berlebih dari makanan bersumber protein khususnya purin. ${ }^{1}$ Namun, terdapat bahan makanan atau minuman yang mengandung senyawa kimia kafein yang dapat menghambat pembentukan asam urat dalam darah. Fungsi kafein tersebut terjadi karena struktur kimia kafein mirip dengan allopurinol. Allopurinol merupakan suatu senyawa yang digunakan sebagai obat menekan produksi asam urat melalui inbibisi kerja enzim xanthine oksidase. Enzim xanthine oksidase adalah enzim yang mereduksi $\mathrm{O} 2$ menjadi $\mathrm{H} 2 \mathrm{O} 2$ dalam sitosol dan sebagai enzim yang mengkatalis hipoxantin menjadi xanthine dan selanjutnya xanthine menjadi asam urat, yang merupakan jalur degradasi purin. Bahan makanan atau minuman yang mengandung kafein diantaranya adalah kopi, teh, cokelat, minuman berenergi, minuman bersoda, dan lainlain. ${ }^{2,7}$

Rata-rata asupan kafein subyek dalam penelitian ini pada kelompok kasus adalah 109,78 mg/hari, sedangkan pada kelompok kontrol adalah $105,83 \mathrm{mg} /$ hari. Asupan kafein yang dikonsumsi subyek sebagian besar diperoleh dari minuman kopi dan teh dengan penambahan gula rata-rata sebanyak 10 gram setiap 1 kali minum kopi ata teh. Hasil uji bivariat menggunakan uji chi square menunjukkan bahwa asupan kafein tidak berhubungan dengan kadar asam urat $(p>0,005)$ dengan OR 0,69. Hasil penelitian ini serupa dengan penelitian di Korea yang menyatakan bahwa asupan kafein tidak berhubungan dengan kadar asam urat dalam darah ${ }^{15}$.

Lemahnya hubungan tersebut disebabkan karena adanya hubungan yang bermakna dari variabel perancu yaitu asupan karbohidrat subyek. Karbohidrat subyek dalam penelitian ini sebagian besar dalam kategori tinggi, yaitu $83 \%$ pada kelompok kasus dan $52 \%$ pada kelompok kontrol. Karbohidrat merupakan sumber kalori utama bagi manusia, dalam tubuh manusia karbohidrat dapat dibentuk dari beberapa asam amino dan sebagian dari gliserol lemak. Tetapi sebagian besar karbohidrat diperoleh dari bahan makanan. Kebutuhan karbohidrat pada orang dewasa adalah
45-60\% dari kebutuhan energi total. Asupan karbohidrat sesuai dengan kebutuhan berfungsi untuk mencegah penggunaan protein sebagai sumber energi sehingga protein dapat disimpan menjadi otot. Namun asupan karbohidrat yang berlebih dalam jangka waktu yang lama akan meningkatkan simpanan lemak dalam tubuh. ${ }^{16}$

Salah satu jenis karbohidrat adalah fruktosa. Fruktosa dalam makanan terkandung dalam bentuk gula dari susunan sukrosa yang dapat terpecah menjadi fruktosa. Asupan fruktosa memiliki efek langsung terhadap peningkatan kadar asam urat. Mekanisme terbentuknya asam urat dengan adanya fosforilasi fruktosa menjadi fruktosa-1 fosfat oleh enzim ketoheksokinase yang dengan cepat menghabiskan ATP dan mengubah ADP dan Pi, selanjutnya ADP diubah menjadi AMP. Sebagai akibat peningkatan penggunaan ATP tersebut, terjadi penurunan Pi yang memicu aktivasi enzim AMP deaminase, yang mengubah AMP menjadi IMP. IMP selanjutnya diubah menjadi hiposantin selanjtnya diubah menjadi asam urat oleh enzim xanthin oxidase. ${ }^{16,17}$

\section{SIMPULAN}

Asupan kafein bukanfaktor risiko dengan kadar asam urat, sebaliknya asupan karbohidrat sebagai variabel perancu secara bermakna memiliki faktor risiko dengan kadar asam urat.

\section{SARAN}

Bagi masyarakat, perlu memperhatikan asupan karbohidrat dalam bahan makanan karena terbukti dapat meningkatkan kadar asam urat dalam darah. Sedangkan untuk asupan kafein, batas yang dapat dikonsumsi adalah $300 \mathrm{mg} / \mathrm{hari}$.

\section{DAFTAR PUSTAKA}

1. Choi HK, Gary C. Coffe, Tea, and Caffeine Consumption and Serum Uric Acid Level: The Third National Health and Nutrition Examination Survey. Arthritis and Rheumatism (Arthritis Care and Research). American College of Rheumatology2007. Vol $57: 5: 816-821$.

2. Choi HK, Mount DB, Reginato AM. Patogenesis of gout. Annals of Internal Medicine 2005 Oct 4, 2005, 143(7): 499-516.

3. Lelyana, Rosa. Pengaruh Kopi terhadap kadar asam urat darah. [Tesis]. Semarang: Magister Ilmu Biomedik Universitas Diponegoro;2008.

4. Angelina, Fransiska. Pengaruh Asupan Kacang Tanah (Arachis hypogaea) Rebus dan Panggang Terhadap Kadar Asam Urat dalam Darah pada Wanita Dislipidemia. Journal of Nutrition College 2014; p2-3. 
5. Riset Kesehatan Dasar (Riskesdas) 2013. Laporan Hasil Riset Kesehatan Dasar (Riskesdas) 2013. Jakarta: Badan Litbangkes, Depkes RI. 2013.

6. Asripa, Rina. Faktor-Faktor yang Mempengaruhi Kepatuhan Diet pada Penderita Asam Urat di Puskesmas Mandiraja 1 Kabupaten Banjarnegara Provinsi Jawa Tengah. [Skripsi]. Purwokerto: Universitas Muhammadiyah Purwokerto;2012.

7. NgocMinh Pham, Daigo Yoshida, MakikoMorita, Guang Yin, Kengo Toyomura, Keizo Ohnaka, Ryoichi Takayanagi, and Suminori Kono. The Relation of Coffee Consumption to SerumUric Acid inJapaneseMen andWomen Aged 49-76 Years. Journal of Nutrition and Metabolism 2010, p7. [Research Article].

8. Peck et al. A Review of the Epidemiologic Evidence Concerning the Reproductive Health Effects of Caffeine Consumption: a $2000-2009$ Update. Food and Chemical Toxicology, June 2010.

9. Diantari, Ervi. Pengaruh Asupan Purin dan cairan terhadapa kadar asam urat wanita usia 50-60 tahun di kecamatan Gajah Mungkur, Semarang. Journal of Nutrition College Vol 2, No 1, 2013 p;44-49.

10. Saag KG, Choi H. Epidemiology, risk factors, and lifestyle modifications for gout. Arthritis Research\& Therapy 2008, 8 (Suppl 1): S2 [Open Access].

11. Setyoningsih, Rini. 2009. Faktor- Faktor yang Berhubungan dengan Kejadian Hiperurisemia pada Pasien Rawat Jalan RSUP Dr.Kariadi Semarang. [Skripsi]. Semarang: Universitas Diponegoro.

12. Purnamasari, Asri Wulan. Hubungan Beberapa Indikator Obesitas dengan Kadar Asam Urat.[Skripsi]. Semarang: Universitas Diponegoro. 2007.

13. Adieni, H, dan Hertanto, W, S. Asupan Karbohidrat, Lemak, Protein, Makanan Sumber Purin dan Kadar Asam Urat Pada Vegetarian. Journal of Nutrition College 2008. Vol. 2, No. 2,p. 44-55.

14. Choi HK, Karen A, Elizabeth WK, Gary C. Obesity, weight change, hypertension, diuretic use and risk of gout in men. Archives of Internal. Medicine 2005;165;742-748. Available at: http://www.internal-medicine.com. By on August 16,2008

15. Bae, Jisuk, Park, Sook Pil, et al. The effect of coffee, tea, and caffeine consumption on serumuric acid and the risk of hyperuricemia in Korean Multi- Rural Communities Cohort. Rheumatol Int (2015) 35:327-336. 2015 (Original Article).

16. Choi Hyon, Curhan Gary. Soft drinks, fructose consumption, and the risk of gout inmen: prospective cohort study. BMJ. [Research].

17. Lina Zgaga, Evropi Theodoratou, Janet Kyle.The Association of Dietary Intake of PurineRichVegetables, Sugar-Sweetened Beverages and Dairy with Plasma Urate, in a Cross-Sectional Study. Plos One Journal. Vol 7. June 2012 